\title{
The Presence of the Bat'a Shoe Company in Central America and the Caribbean in the Interwar Period (1920-1930)
}

\section{Presencia de la Compañía de Zapatos Bat'a en América Central y el Caribe en el periodo de entreguerras (1920-1930)}

\author{
Lukas Perutka \\ Tecnológico de Monterrey, campus Monterrey \\ México, email: 1.perutka@yahoo.com \\ Milan Balaban and Jan Herman \\ Universita Tomáše Bati en Zlín, República Checa, \\ emails: balaban@k.utb.cz; herman@k.utb.cz
}

\begin{abstract}
This article addresses the presence of the famous Czechoslovak shoe company Bat'a in Mexico, Central America, and the Caribbean during the 1920s and 1930s. It is a topic that has not yet been properly researched by historians; therefore this work can shed some light on the activity of Czechoslovak companies in Latin America. The objective is to compare Bat'a's influence in the countries of the respective region and study where it was successful and why and where it was not. This comparative and quantitative analysis is based mainly on the unpublished archive material of Czech and Mexican origin. These sources are supplemented by memoirs of several Bat'a's officials present in the region and published in some local Czechoslovak newspapers.
\end{abstract}

Key words: Bat'a Shoe Company; shoe industry.

Resumen. Este artículo trata sobre la presencia de la famosa empresa checoslovaca de calzado Bat'a en México, Centroamérica y el Caribe en las décadas de 1920 y 1930. Es un tema que hasta ahora no ha sido profundamente investigado por los historiadores y por lo tanto este trabajo puede arrojar alguna luz sobre la actividad de las empresas checoslovacas en América Latina. El objetivo es comparar la influencia de Bat'a en los países de la región mencionada y estudiar dónde fue exitoso y por qué y dónde no. Este análisis comparativo y cuantitativo se basa principalmente en el material inédito de archivo de procedencia checa y mexicana. Estas fuentes se complementan con las memorias de varios funcionarios de Bat'a presentes en la región y publicadas en algunos periódicos checoslovacos locales.

Palabras clave: Compañía de Zapatos Bat'a; industria del zapato.

Am. Lat. Hist. Econ., may.-ago., 2018, pp. 42-76 | DOI: 10.18232/alhe.897 
Fecha de recepción: 21 de junio de 2017. Fecha de aceptación: 30 de octubre de 2017.

JEL: L67; N74; N76; N84; N86.

The work was supported from European Regional Development Fund-Project Creativity and Adaptability as Conditions of the Success of Europe in an Interrelated World (No. CZ.02.1.01/0.0/0.0/16_019/0000734).

\section{INTRODUCTION}

The end of the First World War and the formation of Czechoslovakia in 1918 created new conditions for economic development in the Central European region. President Masaryk's country, Czechoslovakia, was facing several problems related to its transition from war economy to peace conditions and a loss of markets in the former Austro-Hungarian monarchy. With its own market being very limited, Czechoslovak companies were forced to look for outlets abroad, while striving to preserve their position in the successor states of Austria-Hungary. However, export to those states was complicated, mainly due to strict trade barrier protection. Among the largest and most famous Czechoslovak companies oriented toward export were the following companies: Zbrojovka Brno, a Brno company producing machinery and arms; Škoda, a Pilsen engineering company; Vítkovické Horní a hHutní Těžířstvo, a Vítkovice mining and metallurgical company, and Bat'a, the Shoe Company from Zlín. As many other Czechoslovak companies, these firms inherited certain export disadvantages from Austria-Hungary, such as generally weak direct links to foreign markets with a frequent use of intermediary services. Export expansion to far regions and countries was further complicated by the inland position of Czechoslovakia and its dependence on foreign ports. Another obstacle to export was the growing competition on the world market and the shared distrust of unknown goods labelled "Made in Czechoslovakia". A somewhat better situation occurred in the second half of the 1920s but the onset of a major economic crisis and the subsequent wave of protectionism considerably slowed the penetration of foreign markets by Czechoslovak companies.

As the paper deals with Central America and the Caribbean region, our understanding of the studied area calls for a brief comment. Seven mainland countries located between Mexico and Colombia (Belize, Guatemala, Honduras, El Salvador, Nicaragua, Costa Rica, Panama) and the Caribbean islands (Great Antilles, Small Antilles) make up the region of Central America. In the surveyed area, we also included Mexico and three 
other countries located in South America (today's Guyana, Suriname and French Guiana). These three countries, though independent nowadays or autonomous to a large degree, belonged under the colonial rule of various world powers in the 1930s, and shared a similar development and colonial rule to those in the Caribbean islands. The Bat'a Company therefore perceived them as a single export region called "Central America" due to the fact that firms operated there under the same rules.

We have chosen the period between 1932 and 1939 in order to analyse Bat'a's activities in Central America and the Caribbean. At the beginning of the 1930s, Bat'a's goods began to flow into this area, and in 1932, the first company store was opened in the region (in Trinidad). In 1939, (March 15) the Nazi armies occupied the rest of Czechoslovakia, including the company's headquarters in Zlín. That was also the year of the outbreak of the Second World War in Europe (September 1). After that, the Zlín's headquarters were in enemy territory from the perspective of the United Kingdom, France and the Netherlands (and later for the United States). Therefore, it was no longer possible to manage or coordinate businesses in the analysed area. Nevertheless, the Bat'a Company continued to conduct businesses in the region during the war years and the subsequent period, but its activity was managed from newly established headquarters in the USA, and later in Canada.

Describing Bat'a's expansion into Central America and the Caribbean in the 1930s is a rather difficult task as historians have been overlooking the subject so far. The subject has either not been studied at all or has not been paid sufficient attention to. This area shows relatively small involvement in foreign expansion compared to Bat'a's presence in the European, African or Asian markets, which was much larger and better known. ${ }^{1}$ Bat'a's business on those continents is also well documented in several academic works. However, the main obstacle in analysing the Bat'a Company's endeavours in Central America and the Caribbean region is the lack of archival sources. The archive funds of Bat'a's company and its affiliated companies are stored in the State District Archive in Zlín- Klečůvka. Despite its relative completeness, only a minimum of documents kept pertains to the analysed region; there is only a series of export statistics, several newspaper articles, and a few reminiscences stored in the employees' personal cards. Furthermore, there is a complete lack of comprehensive studies on single countries, correspondence with company workers in these countries

${ }^{1}$ For instance, Bat'a's presence in Western Europe was the subject of several works Ehrenbold (2012), Gatti (2004), Ševeček \& Jemelka (2013, 2016), Widmer (1990). Likewise, the company's presence in Easter Europe has been researched by Hrelja \& Kaminski (1971), Kálmán (1974), and Marek (2017). Some historians were even interested in the activities of Bat'a in India, see Baros (1945). 
or work plans for the Bat'a export region of Central America. This condition is likely to have been caused by the events of Second World War, when part of the company's archive was destroyed. Several reports about the Bat'a Company in the region are kept in the Archives of the Ministry of Foreign Affairs and National Archives of the Czech Republic in Prague, in the funds of Czechoslovak Ministry of Finance, or the Czechoslovak Export Institute. These materials are rather of international nature, the originators of which were state ministries, embassies or consulates. In addition, any literary source dealing with Bat'a in Central America and the Caribbean is almost completely missing, except for one short memoir. In spite of this lack in the archival sources, we attempt to describe Bat'a's gradual expansion into Central America and the Caribbean.

\section{BAT’A COMPANY AND ITS EXPANSION INTO OVERSEAS MARKETS}

The history of the Bat'a Shoe Company began on September 21, 1894, when the siblings Anna Bat'ová, Antonín Bat'a and Tomáš Bat'a founded their shoe workshop in the town of Zlín. At the beginning, they started with a joint share capital of 600 Austro-Hungarian guldens inherited from their mother. ${ }^{2}$ After a year in business, they were already employing 50 people, but they also faced a debt of 8000 guldens. Following this crisis, Antonín enlisted for three years in the army, and the youngest Tomáš took over the management of the business. ${ }^{3}$ Under his leadership, the company worked hard to pay off the debt, and introduced a new type of shoes, the so-called Bat'ovky (lightweight cloth footwear). One year later the problems were successfully overcome. At that time, the company won its place in the market and increased the number of footwear produced. However, lo-

\footnotetext{
${ }^{2}$ To estimate an approximate value of the initial assets of the Bat'a siblings, we can use the statistics from 1896, according to which one British pound was worth 24 Austro-Hungarian crowns (1 gulden $=2$ crowns). Conversely, the Bat'a's siblings began with the initial capital of about 50 British pounds.

${ }^{3}$ Tomáš Bat'a (1876-1932) was a Czechoslovak entrepreneur, which was given the monikers "The Henry Ford of the shoe industry" or "The King of Shoes". He was a creator of a world shoemaking empire, and from 1923 to 1932 the mayor of Zlín. He founded his own shoemaking business with his siblings in Zlín, when he turned eighteenth in 1894. In his enterprise, Tomáš Bat'a introduced original methods of production and management, employee motivation and business education. As a mayor, he rebuilt the city of Zlín under the concept of "Factory in Gardens" and founded a garden town with original functionalist architecture. This model of factory and residential neighborhoods with Bat'a's architecture, was also applied to other places in Czechoslovakia, Europe and North America, wherever he built his factory complexes. Tomáš Bat'a died on July 12, 1932 in a plane crash in Otrokovice, the Czech Republic. Under his leadership the company grew into a global enterprise that operated on four continents employing over 31000 people, selling its goods in 2500 own shops, and was engaged in 35 different areas of industry, trade, transport, finance and services.
} 
cal fairs were no longer large enough for its increased production, so the company had to try to access distant markets across the Austro-Hungarian Empire.

Tomáš Bat'a first sold his merchandise through wholesale merchants, selling it wholesale, but in 1909, he focused on retail. He did so through his own travelling salespersons, the so-called Rayonists, who offered shoes to retailers (small merchants and shoemakers) in their designated area, i. e. "rayons" (Hodáč, 2015, p. 191). Tomáš Bat'a changed his sales strategy in 1917, when the Company Bat'a began to set up its own shoe stores and by the end of 1917; the company was operating ten of its own shops in the Austro-Hungarian Monarchy. In the following years, the sales network expanded rapidly and as early as 1920, the company had 70 outlets in the newly established Czechoslovakia. ${ }^{4}$ With the development of own retail network the intermediaries between the producer and the customer were removed, reducing the costs and thus the final price of the shoes.

Soon, the Czechoslovak market became quite small for Tomáš Bat'a's growing enterprise, so he turned his attention to foreign customers. With some help from intermediaries, he started to export his products abroad. The opening of the first shop abroad, in Belgrade in 1919, is considered the beginning of Bat'a's foreign expansion. To understand how the markets abroad function, Bat'a himself went to the United States in 1919 where he explored and learned about the organisation of production, trade policy and social programmes for workers in companies such as Ford and Endicott \& Johnson. In the town of Lynn, Massachusetts, known for its footwear production, Bat'a bought his first shoe factory abroad. In 1919 a sister company Bata Shoe and Leather Co., Lynn, was founded there by Tomáš Bat'a to support his business on the American continent (Pokluda, 2015, p. 16).

After three years in operation, the Lynn factory was closed, but by that time, the company had expanded to European countries with its retail network. In addition to new stores in Yugoslavia, the company opened shops in Romania, the Netherlands and Denmark in 1920-1921. Additional stores sprang up in Norway, England, Egypt and the United States in 1923. Bat'a's shoes were popular for their good quality and affordability among local customers. Bat'a's success, however, presented the local shoemakers with competition. To protect the domestic producers, the states began to raise customs duties, and introduced contingent duties on Czechoslovak footwear, or completely banned its imports (Pagáč, 1926, pp. 290-291).

\footnotetext{
${ }^{4}$ Moravský zemský archiv v Brně, Státní okresní archiv Zlín (SOkA Zlín), fond Bat'a, a. s., Zlín (f. Bat’a), sign. II/3, inventární č. 32, k. 1155. Besides the already mentioned Vienna, the company had its own stores in Zlín, Moravian Ostrava, Brno, Liberec, Prague, Pardubice, Plzen̆, Kladno and České Budějovice.
} 
After 1923, the opening of new Bat'a's outlets abroad was kept on hold, and in 1928, the firm operated its own stores only in the Netherlands, $\mathrm{Yu}-$ goslavia and Egypt (SOkA Zlín, f. Bat'a, sign. I/3, i. č. 63, k. 36).

In the years 1920-1924 Bat'a started to establish foreign affiliates to strengthen its positions abroad. Besides Lynn, a company in former Yugoslavia was founded in 1920 (SOkA Zlín, f. Bat'a, sign. XXVII, i. č. 8, k. 1879). In 1921, another one was established in the Netherlands. In 1922, subsidiaries were set up in Denmark and Poland and in 1924; Bat'a founded a company in England (Lehár, 1960, p. 294). In 1925, the Bat'a Company covered almost half of the Czechoslovak shoe exports, and in 1931, it made up three quarters of it. However, along its success the firm was also encountering a growing number of protests abroad in the mid1920s. Competitors frequently organized manifestations, spread anti-Bat'a leaflets, and local governments were under significant pressure to increase restrictive measures on import to protect local footwear producers. This began in Germany, continued in France at the Congress of the International Association of Shoemakers in Paris, and was followed in 1926-1927 by anti-campaigns in England, Scandinavia and Yugoslavia (Pokluda, 2015, p. 37).

However, a far greater obstacle to exporting Bat'a products was the outbreak of the Great Depression in October 1929. During this crisis, individual countries protected their producers by raising tariff barriers, introducing contingent on imports, and creating various forms of boycott against Bat'a's shoes. All this had a negative impact on the final price of the shoes. ${ }^{5}$ For example, duty fees did not burden import of footwear into the UK at all until the autumn of 1931, when Britain introduced a $20 \%$ ad valorem tax. Depending on the type of footwear, additional duties applied. In India, on January 1, 1932, the duty on leather footwear increased from 15 to $25 \%$ ad valorem; on January 3, 1933, the Ottawa Conference increased the duty for all states not belonging to the British colonial empire to $30 \%$ ad valorem (about 17-18\% of the retail price of shoes). In France, since the introduction of contingent on import of shoes in October 1932, the duty was $30 \%$ of the sales price for leather and $40 \%$ for rubber footwear. In the Netherlands, the duty was $10 \%$ of the value of all footwear; in

\footnotetext{
${ }^{5}$ The leading export representative Alois Gabesam expressed Bat'a's disagreement with customs barriers in the corporate newspaper Zlín on May 8, 1931: "What is the duty? It is a political way of collecting money for the government and protecting less efficient producers from more efficient ones from foreign countries. The duty has never secured the welfare of the population, nor has it increased it. This has been proven by the current restrictions in most European states and by the United States of America, where Senator Watson prophesied prosperity a month after the introduction of the tariffs. Nearly a year has passed and the prosperity of the prophecy has not yet arrived, but on the contrary: shoemaking has seen the same decline as other industries."
} 
April 1932, a contingent was imposed on all footwear, and at the beginning of 1933 a duty of $12 \%$ on luxury goods imported from abroad was introduced (SOkA Zlín, f. Bat'a, sign. XXVI, i. č. 70, k. 1835). In the following years, customs duties changed (see table 1).

Naturally, the increase in tariffs, the introduction of contingent duties and the expensive transport of footwear abroad increased the final cost of shoes, which ultimately became too expensive for the local populations. In order to reduce the price of its products, Bat'a changed its sales strategy again by slowly abandoning sales through intermediaries and going back to selling in its own shops. In 1928, the company's 90\% sales share was in bulk, while in 1935 it was 40\% in bulk and 60\% retail sales (SOkA Zlín, f. Bat'a, sign. I/3, i. č. 63, k. 36). To support the export and sale of his own products, Bat'a started to establish sister companies again in 1929-1932. According to the historian Bohumil Lehár, in the aforementioned years, 24 companies were founded in four continents, thus helping to set up their own retail outlets (Lehár, 1960, p. 294). These stores were established around the world, but most of them were founded in Asia and Africa, where the Bat'a Company had the greatest export potential to export its products. According to its own statistics at the end of 1932, Bat'a was selling goods abroad in 666 shops in 37 countries (SOkA Zlín, f. Bat'a, sign. XXVI, i. č. 70, k. 1835).

To circumvent the high tariffs, the contingent restrictions, and the import bans of its products, Bat'a was forced to transfer production to other countries. The manufactured footwear in these factories was not subjected to import restrictions, and shoe exporting to the colonies of individual countries was more financially convenient in comparison with importing goods from Zlín. In addition, factories abroad could import parts of footwear from Czechoslovakia, which again was not subjected to import duties, and then assemble ready-made footwear. In 1931, a new factory in Germany (Ottmuth) was opened. A year later, other plants in Poland (Chelmek), Switzerland (Möhlin), France (Hellocourt), and then Yugoslavia (Borovo) were founded. This was followed by opening of factories in India (Konnagar) and England (Tilbury) in 1933, and a year later founding operations started in the Netherlands (Best) (Pokluda, 2015, pp. 37-39).

In July 1932, the founder of the company, Tomáš Bat'a, died in an air crash in Otrokovice. The management of the company was taken over by 


\section{TABLE 1. DUTIES IN CSK (CZECHOSLOVAK CROWNS) PER PAIR OF FOOTWEAR IN 1937}

$\begin{array}{lrr}\text { Country } & \begin{array}{l}\text { Duties in crowns per pair of footwear } \\ \text { Leather }\end{array} \\ \text { Rubber } \\ \text { Spain } & 115 & \\ \text { Venezuela } & 97 & 24 \\ \text { Mexico } & 80 & 12 \\ \text { Brazil } & 59 & 22 \\ \text { France } & 34 & 36 \\ \text { Canada } & 32 & 42 \\ \text { Czechoslovakia } & 15 & 91 \\ \text { The Netherlands } & 14 & 6 \\ \text { Great Britain } & 8 & 10 \\ \text { USA } & 7 & 28\end{array}$

Source: SOkA Zlín, f. Bat'a, sign. I/3, i. č. 63, k. 36.

a three-member board of directors, Jan A. Bat'a, ${ }^{6}$ Dominik Čipera $^{7}$ and Hugo Vavrečka, ${ }^{8}$ who continued the trend of expansion abroad -expanding the number of stores, creating sister companies, and building new

${ }^{6}$ Jan Antonín Bat'a (1898-1965) was Tomáš Ba'a's stepbrother. He had been working for the company since his youth, and in 1920 he unsuccessfully managed a company factory in Lynn in the US. After the death of Tomás Bat'a, Jan became the owner of the company's shares and its chief representative. Together with D. Cipera and H. Vavrečka, he successfully continued the development of the company until the beginning of the Second World War. In June 1939, he went to the US. During the war he was included in the English and American "black list" due to his activities and was forced to leave the US for Brazil. At the same time, he lost influence in the management of the Bat'a companies. After the war he decided to stay in Brazil, as he was sentenced to fifteen years in prison in a politicized process in Czechoslovakia. He litigated, almost until his death, with his nephew Tomáś Bat'a Jr. about the property of the Bata Shoe Organization.

${ }^{7}$ Dominik Cipera (1893-1963) joined the Bat'a Company in 1919. He was in charge of accounting and finances in the company. Since 1925 he was a proxy of the company and therefore the second man in the firm hierarchy. After the death of Tomás Bat'a, he took over the office of the mayor of Zlin, in which he served until 1945. In May 1945, after the end of war in Europe, he was deprived of his authorities, and in March 1946 he was let go from the nationalised Bat'a company. In May 1948, he emigrated to London and later to Canada, where he helped Tomás Bat'a Jr. develop Bata Shoe Organization.

${ }^{8}$ Hugo Vavrečka (1880-1952) was a Czechoslovak diplomat who joined Bat'a in June 1932 as a director of Bat'a's economic, business and diplomatic relations with partners in Czechoslovakia and abroad. During the Second World War he supported the Czechoslovak resistance movement, as did Dominik Cipera, but in May 1945 he was removed from the company, and in March 1946 he was let go from the nationalized Bat'a Company. He was the grandfather of the former Czechoslovak president and later Czech president Václav Havel. 
manufacturing facilities. In 1933, a new factory began its production in Beirut (Lebanon). In 1937, plants opened in Jakarta (Indonesia), Singapore and Vernon (France), and a year later in Egypt. Under the leadership of the three-member directorate, the distribution of Bat'a's products in the world changed; while in 1928 84\% of the products were sold in Europe, 2\% in Asia and Australia, 6\% in Africa, and 8\% in the American continent, in 1935 only $32 \%$ was sold in Europe. The sales focus moved to Asia and Australia, where 15\% of all goods was sold, an additional 24\% in Africa, and 29\% in America (SOkA Zlín, f. Bat'a, sign. I/3, i. č. 63, k. 36).

The trend of export expansion into overseas (non-European) regions can be clearly seen from the data. In 1929, Czechoslovakia exported 6224000 pairs of shoes outside Europe, of which the Bat'a company comprised only 28\%, while in 1931 the company's share in Czechoslovak exports to non-European countries was already 59\% (Bat'a exported 3116000 pairs of shoes). In 1932 the company export share further increased to 75\% (the company exported 5600000 pairs of shoes). From 1933 till the onset of the Second World War, Bat'a was almost a sole exporter of Czechoslovak footwear to overseas areas, as its share of exports ranged between 95-98\%, and the volume of exported shoes increased from 6413000 pairs (in 1933) to 10034000 pairs (in 1938) (SOkA Zlín, f. Bat'a, sign. I/3, i. č. 63, k. 36$)$.

Prior to the outbreak of the Second World War in Europe, the Bat'a company operated more than fifty sister companies in more than thirty countries and sold its merchandise in more than 90 nations (SOkA Zlín, f. Bat'a, sign. X, i. č. 118, k. 1541). All managed and orchestrated from the Zlín headquarters. The company employed around 65000 people (of which 23250 were employed abroad). In many countries, Bat'a shoes became widespread goods, and often the most famous Czechoslovak product and a synonym for Czechoslovakia (Pokluda, 2015, p. 60).

\section{Overview of the Great Depression in Central America AND THE CARIBBEAN}

The Great Depression of 1929, mainly associated with the stock market crash on Wall Street, affected Latin America in the same way it affected Europe or the United States. The problems started soon after the First World War when the conjuncture of the conflict was already over. The countries we are focusing on in this article were severely damaged because of their economic export-import model. With the exception of Mexico, the countries in Central America and the Caribbean were dependent on agricultural exports -coffee, sugar, tobacco, bananas and their world mar- 
ket prices plummeted in the 1930s. Mexico was exporting mainly metals and minerals, and its economy was also affected, although not as severely due to the fact that the global value of their major export commodity, i.e., silver, rose in this era.

The government of Herbert Hoover attempted to counter the effects of the crisis, but eventually it made it worse and even global. This was due not to what Hoover did but to what he failed to do, his inactivity. Firstly, he did not prevent the withdrawal of US capital from abroad and secondly, he did not veto the instalment of protectionism. Both inactions had similar repercussions in Europe, Latin America and the rest of the world (Kindelberger, 1985, pp. 153-159, 182-186).

Nevertheless, not only the global crisis badly affected many states. Mexico, for instance, avoided the First World War even so it endured a decade-long devastation through its own revolution. In the 1920s, it enjoyed no respite as the army rebelled twice. The infamous Cristero rebellion brought more bloodshed and as a conclusion, the president-elect Alvaro Obregon was assassinated in 1928 (Knight and Drinot, 2015, pp. 272-278). Other countries in the region experienced a similar turbulent development. Some were even occupied by US troops, as in the case of Nicaragua, Cuba, and Dominican Republic. Along with the unstable political situation, the economy did not thrive either in the 1920's. After the First World War conjuncture, the prices of export products from Central America and the Caribbean experienced a steep drop. Notwithstanding, even after stabilisation, the main products of this area such as coffee, sugar or bananas peaked before the Stock Market Crash in 1929. The immense problem was that the countries did not diversify their portfolio of products and one to three products usually accounted for 50 percent of their foreign exchange earnings (Bulmer-Thomas, 2003, pp. 189-191).

After the crash, a chain reaction started. As the world prices of export products fell, so did its volume. Foreign currency reserves in Latin American countries diminished and so did their ability to pay for imports. The decline of world demand led the trade to go down, as nobody wanted to sell any merchandise below its production value (Coatsworth \& Williamson, 2002, p. 16). Regarding global commerce, only one aspect remained stable -the fixed nominal interest on public and private foreign debt. This, though, was of no benefit to Latin American countries, which were constantly battling their foreign commitment.

The combination of unchanged debt service payments and falling export receipts exerted a strong squeeze on imports. As the volume and value of imports fell, governments had to come to terms with a new problem caused by the heavy dependence of fiscal revenue on external trade taxes. The principal source of gov- 
ernment revenue, the tariff on imports, could not be maintained in the wake of an import collapse (Bethell, 2008, p. 79).

To conclude, we can point out that in the years prior to the crisis and until the recovery in the mid-1930s the independent countries of Central America and the Caribbean issued direct and indirect policies of protectionism that also affected Bat'a and his efforts to enter these markets.

The company's chances were better in the Caribbean area, and especially in the American, British, Dutch and French colonies. The authors describing the struggle of the Great Depression divide these powers into those who abandoned Gold Standard quickly (Great Britain in 1931, the US in 1933) and those who did it later (France, the Netherlands in 1936). Nevertheless, when comparing the levels of their protectionism the differences were negligible and the outcomes were similar. Countries that remained on the Gold Standard, keeping their currencies fixed, were more likely to restrict foreign trade. With other nations devaluing and gaining competitiveness at their expense, they resorted to protectionist policies to strengthen the balance of payments and limit gold losses (Eichengreen \& Irwin, 2010, p. 872).

We have already mentioned the US tariff policy. A similar one was adopted by Great Britain in 1932, although the demand had been there before. After a series of debates and especially the important conference in Ottawa, the introduced tariff was 10\% on almost all imports except those from the countries of the British Empire (Rooth, 1993, pp. 83-89). The remaining two imperial powers, the Netherlands and France, stayed in the Gold Bloc until 1936. Their economies may not seem very protectionist at the first glance, but they eventually followed the example of Britain and the US, only by different methods. When the United Kingdom imposed their Import Duties Act, the "Gold Bloc countries raised tariffs and tightened quotas on imports in effort to insulate their economies from the downturn and protect their gold reserves" (Eichengreen \& Irwin, 2010, pp. 877-879).

Even though all countries in the world issued measures of protectionism, Bat'a had at least two more advantages in the colonies of imperial powers than in the independent states of Central America and the Caribbean. First, the demand for import goods did not decrease significantly in the colonies despite mother countries issuing protective measures. Second, thanks to his entrepreneurship, Bat'a founded factories and companies in the colonial powers (US, Britain, France and the Netherlands), which facilitated export and helped him bypass their protective restrictions. 


\section{BAT'A IN MEXICO}

The Great Depression affected the whole world; therefore, it also had an impact on Bat'a's export policy. He realised that the volume of foreign trade decreased so he observed the urgent need to diversify the portfolio of trade partners. The traditional countries were unable to import the same amount of his merchandise as before the crisis, so he logically assumed his need to access more markets. One of these were also Central America and the Caribbean. However, every country had been regulating its trade in a different way. Some adopted very strict measures of protectionism, while others decided to keep their old tariffs. Such ambivalence is the reason why we need to assess the respective countries in an individual way and not en bloc.

Mexico was obviously the biggest and wealthiest country in the area, yet it is surprising that the import of Bat'a's shoes was negligible. On the other hand, Bat'a made significant efforts to get in the Mexican market. Through diplomatic channels at the end of 1930s, he first tried to map the situation on the market by analysing the export and import of shoes in 1928 and 1929. Apart from the volume, he asked for the price and for countries that imported from Mexico and which Mexico exported from (AHGE, exp. IV-525-47). The following year Bat'a went directly to the Legation of Mexico in Prague. This time the company representatives asked for more specific information, such as the tariff on various types of shoes and also the conditions to establish foreign institutions in Mexico. Bat'a intended to open a branch office in the capital city and wanted to sell the following types of footwear there: leather shoes, textile shoes with leather sole, canvas shoes with rubber outsole, silk satin shoes with leather sole, and brocade shoes with leather sole (AHGE, exp. IV-594-3) (see figure 1).

Although the Mexican official in charge of business affairs in Prague, Leopoldo Blasquez, was interested in attracting Bat'a to Mexico, as he realised the importance of the company, ${ }^{9}$ the conditions set by his government were not accepted. We can only assume why Bat'a refused them, but if we evaluate them closely, they were far from welcoming to foreign investments as they were in line with the policy of protectionism. First, Bat'a must have realised that Mexico was a country with a strong internal shoe market. The factories in Leon, Guanajuato, were famous worldwide for their leather footwear. Therefore, the competition was not only particularly powerful but also protected by the government. The tariffs sent to Bat'a by Blasquez were far from acceptable. They almost doubled the

\footnotetext{
${ }^{9}$ In his message to his government he talks about "a great factory" that employs 16000 people and produces 100000 shoes per day.
} 


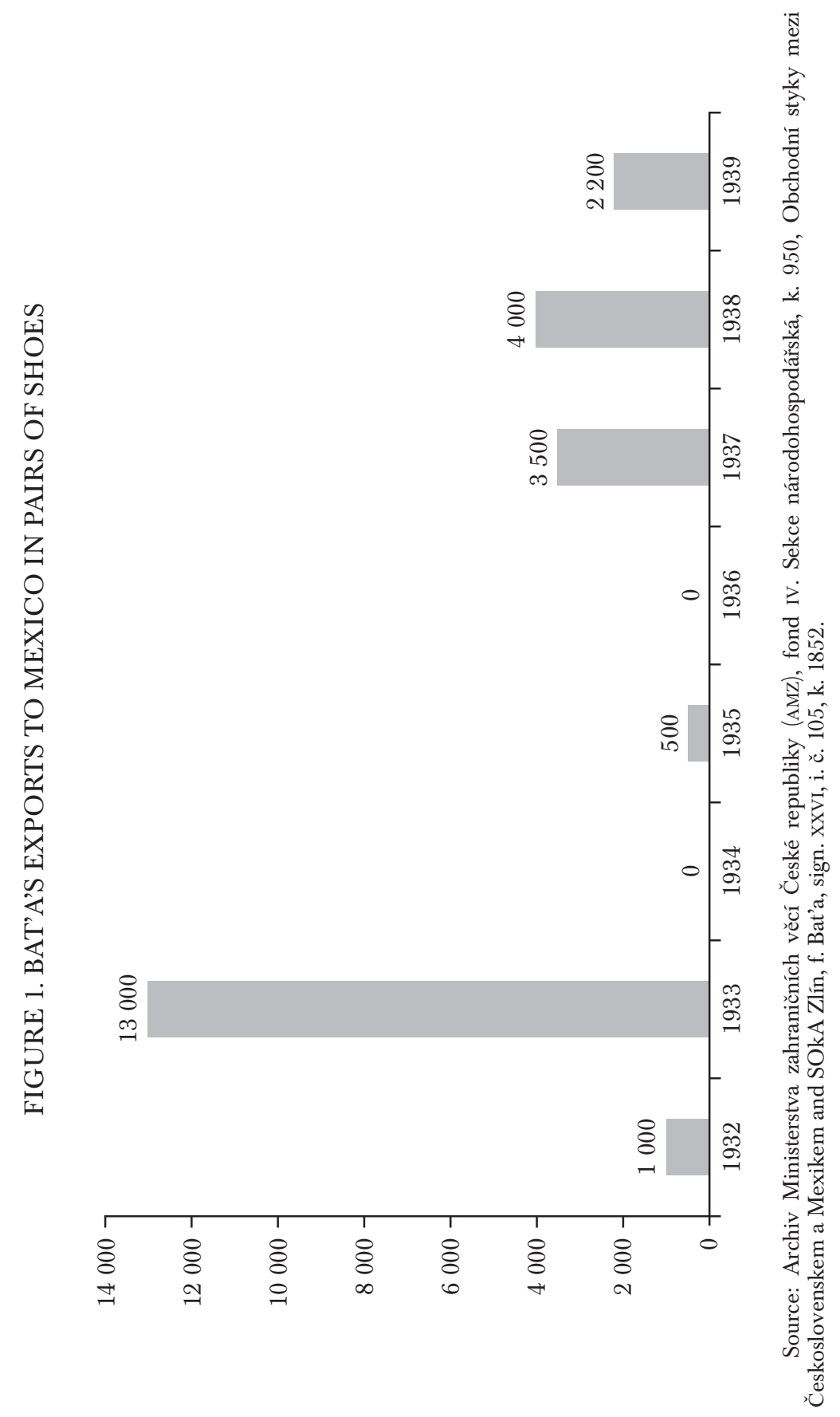


price of Bat'a's products, making them unable to compete. Even the opening of a shop in Mexico was not an easy task. According to the new Trade law (Código de Comercio), the owner of a foreign company could open a branch office only when he had residency in the republic and complied with the following four points: a valid legal status confirmed by the diplomatic mission of the respective country, obedience to the Mexican law, sufficient capital, and a representative who would observe the needs of the society -therefore of Mexican nationality. Only then an office could be established, and then operate under somewhat complicated local laws (AHGE, exp. IV-594-3).

Even after this setback, Bat'a started to import shoes in Mexico, but the outcome was not what it was expected to be. According to the numbers provided by the Czech Ministry of Foreign Affairs, in 1932 Bat'a exported to Mexico 1000 pairs of shoes for 78000 crowns. A year later it was 13000 pairs for 300000 crowns, which was the highest number preceding a steep decline. We have no data for 1934. It is therefore possible that not a single shoe was exported, and in 1935 the value of traded goods was a negligible amount of 1000 crowns (AMZ, fond IV. Sekce národohospodářská, k. 950, Obchodní styky mezi Československem a Mexikem). It was no surprise that the company, in cooperation with other Czechoslovak exporters, persuaded the government to sign a commercial treaty with Mexico.

This had been an ongoing debate at the Czechoslovak Foreign Affairs Ministry, which started in 1926 when Mexico cancelled many of its commercial contracts with European countries. However, the preliminary talks were unsuccessful because of the passivity of Czech diplomats (AMZ, f. IV. Sekce národohospodářská, k. 950, Ministerstvo zemědělství to Generální konzulát v Mexiku, 24. 3. 1927, document 22269-VI). The debate resumed after the Great Depression, yet it was not serious until 1933, when the Czech economic representative in Mexico Vladimír Krupka sent to Prague a proposal of a commercial treaty valid for one year. The offer was not refused but it took four more years to finalise the treaty. It was only after Lázaro Cárdenas took the presidency and the Czechoslovak Foreign Affairs Ministry sent Vlastimil Kybal to Mexico. Cárdenas was very interested in the diversification of business partners for Mexico in order to diminish the role of the United States. So, when he met Kybal, not only did he become his friend, but he also offered him close cooperation. Kybal welcomed the proposition, as one of the goals of his mission was to strengthen the economic relations with Mexico. Nevertheless, it took both governments several years to finally sign the treaty. A Mexican decree that raised the tariffs on several goods from January 1937 was crucial for the deal. In order not to damage Czech merchandise, the commercial treaty was signed on November 6, 1937, and it guaranteed both 
countries the highest benefits regarding import tariffs (AMZ, f. IV. Sekce národohospodáŕská, k. 950, Kybal to Hay, 6. 11. 1937, d. n. 2412/37). Although the deal was never ratified as Czechoslovakia was torn apart after the Munich Agreement in September 1938, it facilitated commercial exchange between both countries.

The effects can be seen in the numbers of shoe imports by Bat'a. In 1937 it amounted to 3500 pairs of shoes with a value of 38000 Czechoslovak crowns. In 1939 due to the Second World War it was just 2000 pairs for 17000 crowns (SOkA Zlín, f. Bat'a, sign. XXVI, i. č. 105, k. 1852). Nevertheless, the real potential was seen in the year 1938 before the Central European country was absorbed by Hitler's Germany. In that period, the commercial treaty had not been ratified but there were many expectations reflected in the trade between both nations. We can track this effect also in Bat'a's exports. The company delivered 11061 pairs of shoes in Mexico, and almost half of these were expensive all leather type. The total value of all the merchandise, including toys, tyres, stockings and other small goods was 170207 crowns. It was the second best year for Bat'a in Mexico in the interwar period thanks to the depreciation of the peso and the commercial agreement (SOkA Zlín, f. Bat'a, sign. XXVI, i. č. 76, k. 1840; i. č. 74, k. 1838).

\section{Bat'A's enterprises in CENTRAl America ANd the CARibbean}

The expansion of Bat'a into Central America and the Caribbean is documented as early as 1929, when 200 pairs of footwear were exported from Zlín to Curaçao Island. A year later, hundreds of pairs of shoes began to flow from Zlín to the Caribbean islands of Barbados, Grenada, Haiti, Jamaica, Martinique and Trinidad as well as Guatemala, Nicaragua, Panama, Guyana and Suriname. In 1931, exports to Bermuda and Saint Lucia began (SOkA Zlín, f. Bat'a, sign. X, i. č. 118, k. 1541) (see map 1).

The Central American and Caribbean region consisted of several countries that belonged to the interest sphere of various powers -the United Kingdom, France, the Netherlands and the USA. For this reason, customs tariffs, sales opportunities and trade relations were very different in these countries. Since October 1929, economic crisis gradually hit all the countries of the region and manifested in them with varying intensity, especially regarding interdependence of the countries and spheres of interest of the great powers. Political instability in the region and constant currency fluctuation in individual countries hindered Bat'a's exports, so the company mostly used the US dollar for international trade in the area. In 1931, Bat'a exported 197000 pairs of shoes to the region (with a value of 


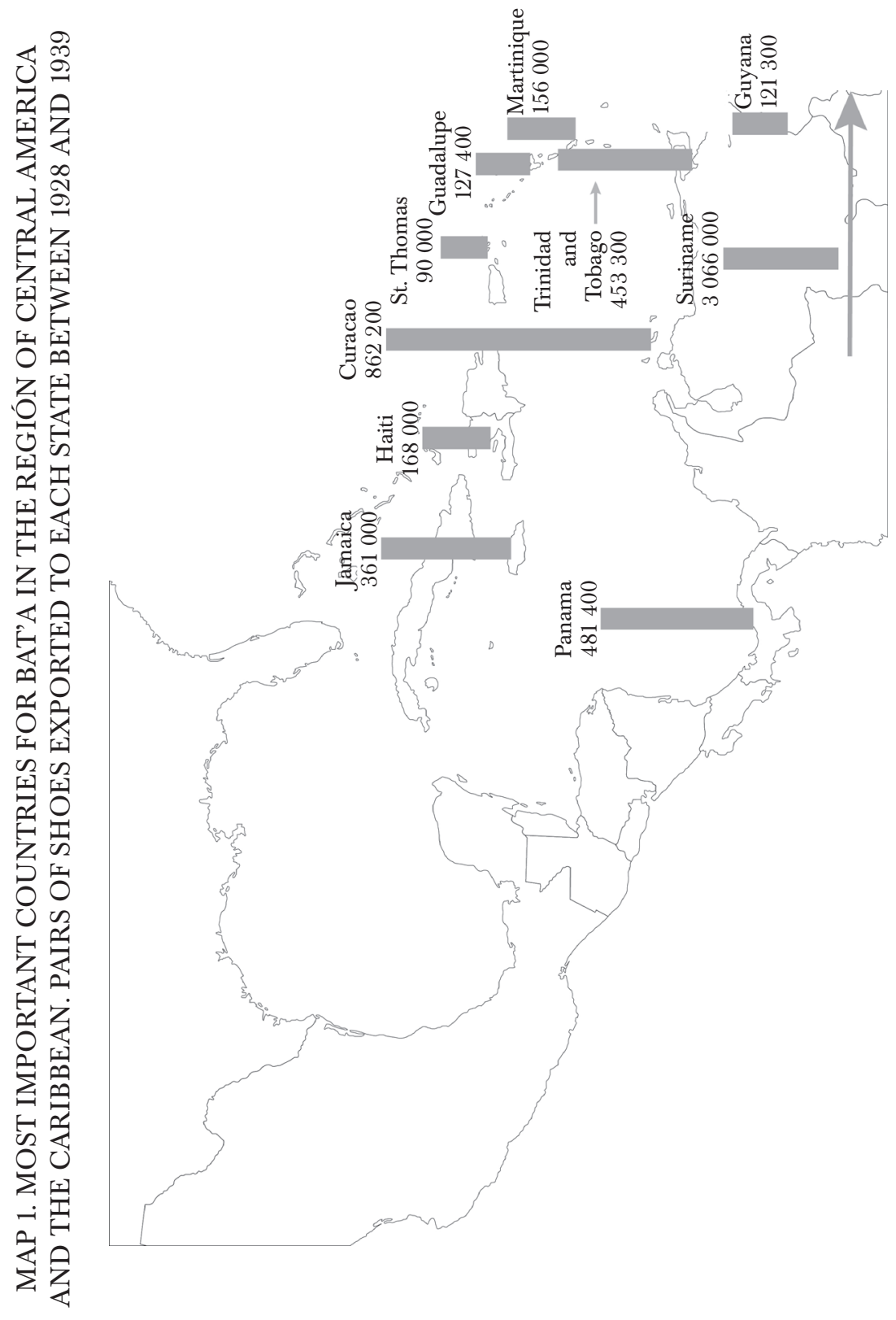

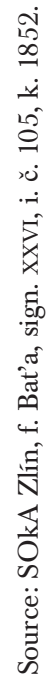


4661000 Czechoslovak crowns), and a year later it exported 192000 pairs worth 3146000 crowns. However, cheaper shoes of Japanese and Canadian competitors heavily undermined the company exports. Moreover, the Ottawa Conference introduced higher duties on products from countries outside the British Empire (SOkA Zlín, f. Bat'a, sign. XXVI, i. č. 70, k. 1835).

The sales of Bat'a's shoes in Central America and the Caribbean began in 1929 as in bulk sales. To increase the sales, Bat'a once again changed his policy, and in 1932 he opened own retail outlets. The company had originally chosen Trinidad for its headquarters in the area, but later moved its seat to Jamaica. The sales manager in the region was Arpád Ronai (SOkA Zlín, f. Bat'a, sign. II/2, i. č. 87 , k. 1121, p. č. 18)..$^{10}$

The first Bat'a store in Trinidad in Port of Spain (on Frederick Street) opened in the first half of 1932; at the end of the year three bazaars were added to the sales network -Port of Spain (Charlotte Street), Sangre Grande and San Fernando. Trinidad became one of the most important outlets in the region for Bat'a. Factory production of shoes on the island did not exist, and the local shoemakers manufactured only footwear called "alpargatas" (light canvas shoes), which were mainly used in the interior of the island and did not present any competition to Bat'a's products. In 1932, the company exported 53000 pairs of shoes to the country and earned 1346833 crowns (US\$ 6422 ). Trinidad, as a British colony, was closely intertwined with the UK economy. Following the adoption of the Ottawa Conference decisions, a higher duty was imposed on non-English products, which, for example, amounted to $13-15 \%$ of the sales price of leather shoes and 50\% of the rubber footwear (SOkA Zlín, f. Bat'a, sign. XXVI, i. č. 70, k. 1835). Therefore, business in the country was managed by a sister company, British Bata Shoe Company Limited, Trinidad department, which as a British company used its financial relief for imported goods (SOkA Zlín, f. Bat'a, sign. XXVI, i. č. 79, k. 1842). In the following years, Bat'a opened additional stores in Trinidad, which also provided pedicure services to its customers. Every year, the company exported tens of thousands of pairs of shoes, from Zlín to the island, which were sold at 18 stores in 1938, according to the firm's own statistics (SOkA Zlín, f. Exico, i. č. 5, k. 1). There, in addition to leather, canvas and rubber footwear, customers could also buy other company products -stockings, tires, or rubber toys (SOkA Zlín, f. Bat'a, sign. XXVI, i. č. 73, k. 1937).

${ }^{10}$ Arpád Ronai was born on February 3 1908. After several months of employment as Herstal's sales representative in Brussels, he was hired by the Bat'a export department on March 8, 1932, where he worked in the US Rayon and later in the Central America region. In order to have a better control of the Central American Rayon, he settled in Kingston, Jamaica. After the war, he served as a Belgian consul in Jamaica, and from 1955 to 1973 he managed the Bata Company retail business at Curaçao. 
With the help of a sister company, British Bata Shoe Company Limited, based in Tilbury, Bat'a managed to supply and do business in other Central American countries that fell into the British sphere of influence. These were the islands of Antigua, Barbados, Jamaica, Grenada, Dominica, Saint Kitts and Saint Lucia, Saint Vincent and Trinidad. On the mainland, the company from Tilbury conducted business in Guyana (SOkA Zlín, f. Bat'a, sign. XXVI, i. č. 79, k. 1842). The lack of sources unfortunately does not allow for a reconstruction of the business processes in individual countries. According to the export value, the most important outlet was in Trinidad, followed by Jamaica, but Bat'a's business on the island of Saint Lucia had a very interesting narrative based on the memoirs of Karel Pešek published in the local newspaper Zlin in 1938 (Zlin, 22. 6. 1938, p. 3).

In 1934, an employee of the Bat'a Company, Karel Pešek, traveled from Zlín to St. Lucia. On arrival, he found a suitable place for a store in the largest city of Castries and opened it within ten days. There was a great demand for Bat'a's footwear among the local people, which Pešek promoted with a special advertising campaign. On his evening walks through the city, while he wore exemplary good shoes, he used to give sweets to the local children, without telling them who he was. The newly received stock of goods from Zlín, was always exhibited in the shop window, raising interest in the company's store. As another promotional activity, he himself recalls:

I have come up with a new way of advertising just now. We took both children for the evening walks with us, and I gave my oldest daughter leaflets. That was new to Santa Lucia. No one ever uses leaflets, and especially not a white man -and do not take this the wrong way, a proud father of a beautiful girl. People enjoyed our activity very much, thanked for the brochures and promised to visit us in the shop. I use every opportunity for advertising (Zlín, 22. 6. 1938, p. 3).

To increase sales, Pešek travelled around the island by car and animals, and offered the company's footwear in remote places.

We travelled along the paths between the plantations, along the coast or along the footpaths on the hillsides of the mountainous interior of the island, resting in the shade of trees or lonely buildings, drinking from the springs, eating whatever grew around, and I felt like one of the apostles proclaiming the teachings of Christ.

In several places, he acquired wholesale customers (Soufriere, Vieux Fort), so the sales of Bat'a products in St. Lucia flourished. After four years, in 1938 Pešek left the island, leaving behind a network of wholesale dealers and a company shop with a weekly turnover of 100000 crowns, which 
was one of the best results of all Bat'a stores throughout Central America and the Caribbean (Van̆hara, 1994, p. 237).

The French sister company Bata S. A., headquartered in Strasbourg, conducted business on the islands of Guadeloupe, Martinique and French Guiana (SOkA Zlín, f. Bat'a, sign. XXVI, i. č. 79, k. 1842). Shoes to these countries were supplied by factories from Zlín and Hellocourt in France, but the quantity of imported goods reached only average figures within the region analysed in this paper. Václav Macák who came to the island after Easter in 1935 and was employed as an assistant of Bat'a retailer Dr. Netopil, in the company store in Pointe-à-Pitre, left a report on business in Guadeloupe. It was his sports talent that soon made him a member of the local football team and helped them win the local championship. $\mathrm{He}$ gained a considerable popularity, which in return helped immensely in advertising the company products. Macák remembers: "Because I did not have any football boots, I took a pair of plimsolls out of the shop. I started, completely accidentally, a new trend on Guadeloupe pitches [...] Of course, nobody knew me under the name of Macák. For journalists, as well as for fans, I was Bat'a" (Zlín, 14. 12. 1938, p. 3).

At that time, several Guadeloupe enthusiasts established an aero-club. They had a small plane, and Bat'a's employees used it to continue their original advertising campaigns. Dr. Netopil decided to fly around the island, spreading company leaflets.

Until then, there were just a few Guadeloupians who had seen a plane, so the effect of this great bird on remote villages [...] was stunning. People fled in their houses in confusion, and only when they saw the multicoloured leaflets of our advertising falling out of the sky they decided to come out for that colourful mix. There was always somebody who would read them, and then we had whole delegations in the shop several times a month, who came to buy the shoes that fell from heaven (Zlin, 14. 12. 1938, p. 3).

Successful business on the island continued in 1936 when Bat'a intended to import "at least 100-120 000 pairs of plimsoll footwear from Hellocourt and 100-120 000 pairs of better shoes from Zlín" (SOkA Zlín, f. Bat'a, sign. I/4, i. č. 25, k. 68). To increase sales, Václav Macák was commissioned, at the end of 1936, to open another store in Grand Bourgu on the island of Marie Galante. In the year 1938 another new shop was opened, so the company had three outlets on the Guadeloupe islands in that very year (SOkA Zlín, f. Bat'a, sign. I/4, i. č. 25, k. 68).

Most of Zlín footwear exported to Central America and the Caribbean went to Curaçao and Dutch Guyana, present-day Suriname. Exports there started at the turn of the 1920s and 1930s. In the following years, 
exports grew stronger and before the Second World War they reached the highest numbers in the whole area of our research. An important role was played by the fact that the Netherlands and its colonies did not introduce such high restrictive measures and customs duties on footwear as the other states did within their influence zones in Central America and the Caribbean (see table 2). The company business in those regions was managed by a Dutch sister company N. V. Nederlandsche Schoen en Lederfabrik Bata, with its seat in Best. It was a modern factory, which together with footwear from Zlín supplied Curaçao and Surinam (SOkA Zlín, f. Bat'a, sign. XXVI, i. č. 79, k. 1842).

The American company Bata Shoe Company Inc. with the headquarters in New York, managed business operations in separate countries in the region -Mexico, Panama, Haiti, the British territories of Belize and Bermuda, as well as on the American Virgin Islands-St. Cross, St. Thomas (SOkA Zlín, f. Bat'a, sign. XXVI, i. č. 79, k. 1842).

Tables 2 and 3 show the amount of footwear exported from the Zlín factories to the countries of Central America and the Caribbean. However, they do not list other exported footwear from company factories in England, France and the Netherlands, which, as domestic products, were not subjected to increased duties on exports to Central American countries.

When exporting goods overseas, especially to tropical areas, a large financial loss to the goods arose due to heat and humidity, causing damage during transport and storage. Salty and humid air caused moulding of the leather parts of the boots. The rings in the lining and the nails in the sole rusted, and the varnish was stained and cracked due to dampness. Because of long storing, the rubber outsole petrified, broke, and under sun exposure, white shoes became yellow. Bat'a's gold staining oxidised, the leather heels shrank while glue seeped out of them, and as a result, the heel would often fall off. Also, the equipment in the stores rusted, and so did the chairs and shelves in the window. The chrome plating was poorly protected against the rust, the pedicure tools had to be sterilised more often due to rapid rusting, and the glued boxes disintegrated during transport, because the adhesive would dissolve. Therefore, the boxes were not glued anymore, instead they were made with iron hooks, which, however, also rusted due to the humid conditions, and in case of an injury blood poisoning was a real threat (SOkA Zlín, f. Bat'a, sign. I/4, i. č. 25, k. 68).

In 1938, the Bat'a Company in Central America and the Caribbean was selling its products in 56 of his own stores in 17 territories (see table 4). In the remaining countries, the company offered wholesale goods to customers through intermediaries. In general, business in the Caribbean was simpler than on the mainland. The most important markets were the Caribbean islands of Trinidad and Curaçao, and on the mainland, Panama 


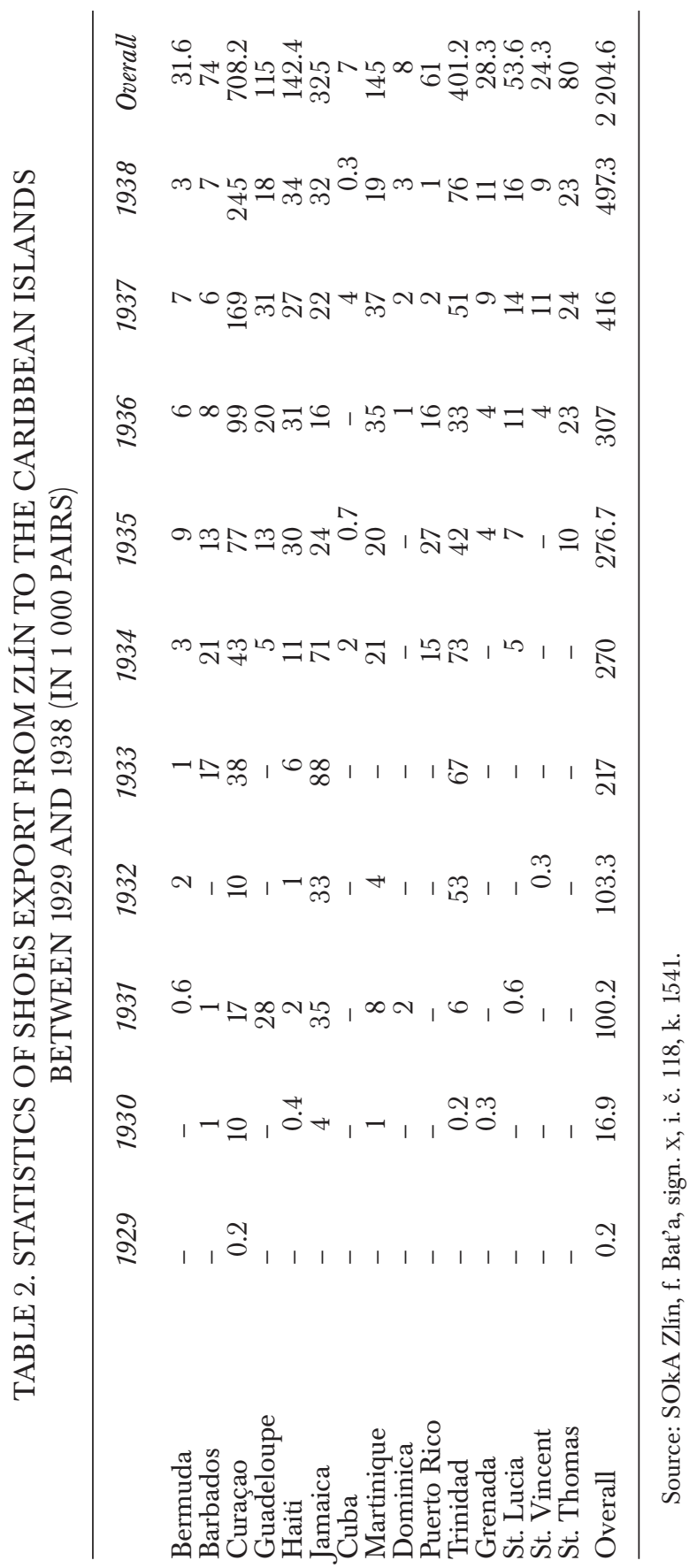




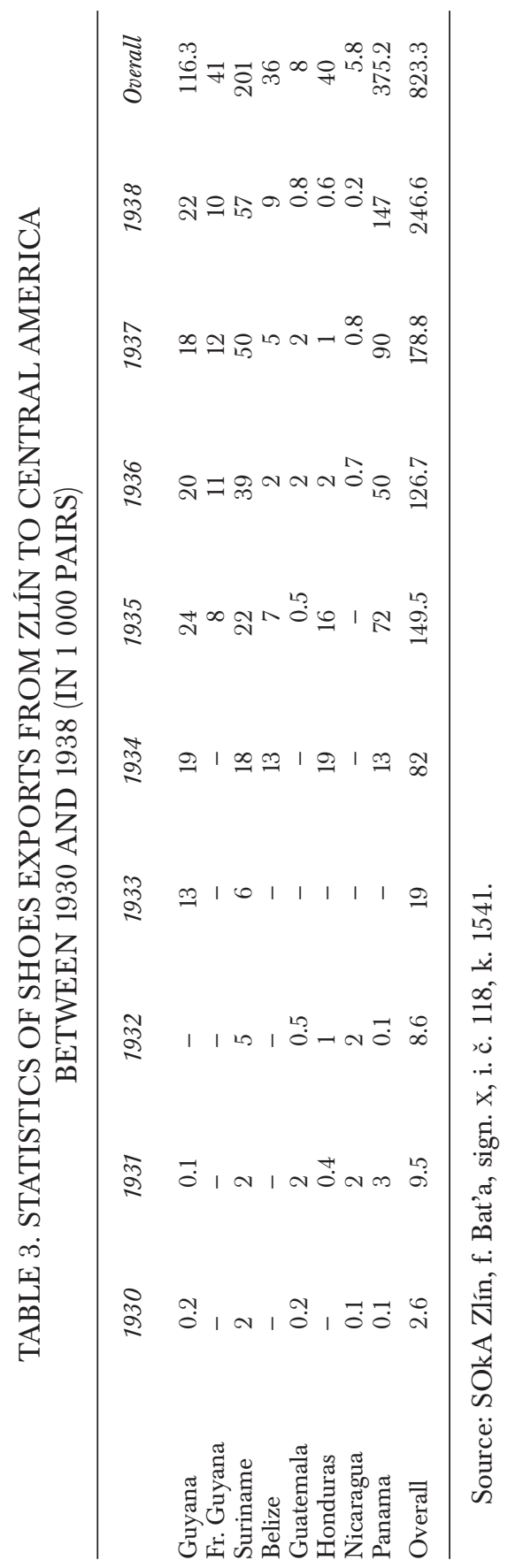




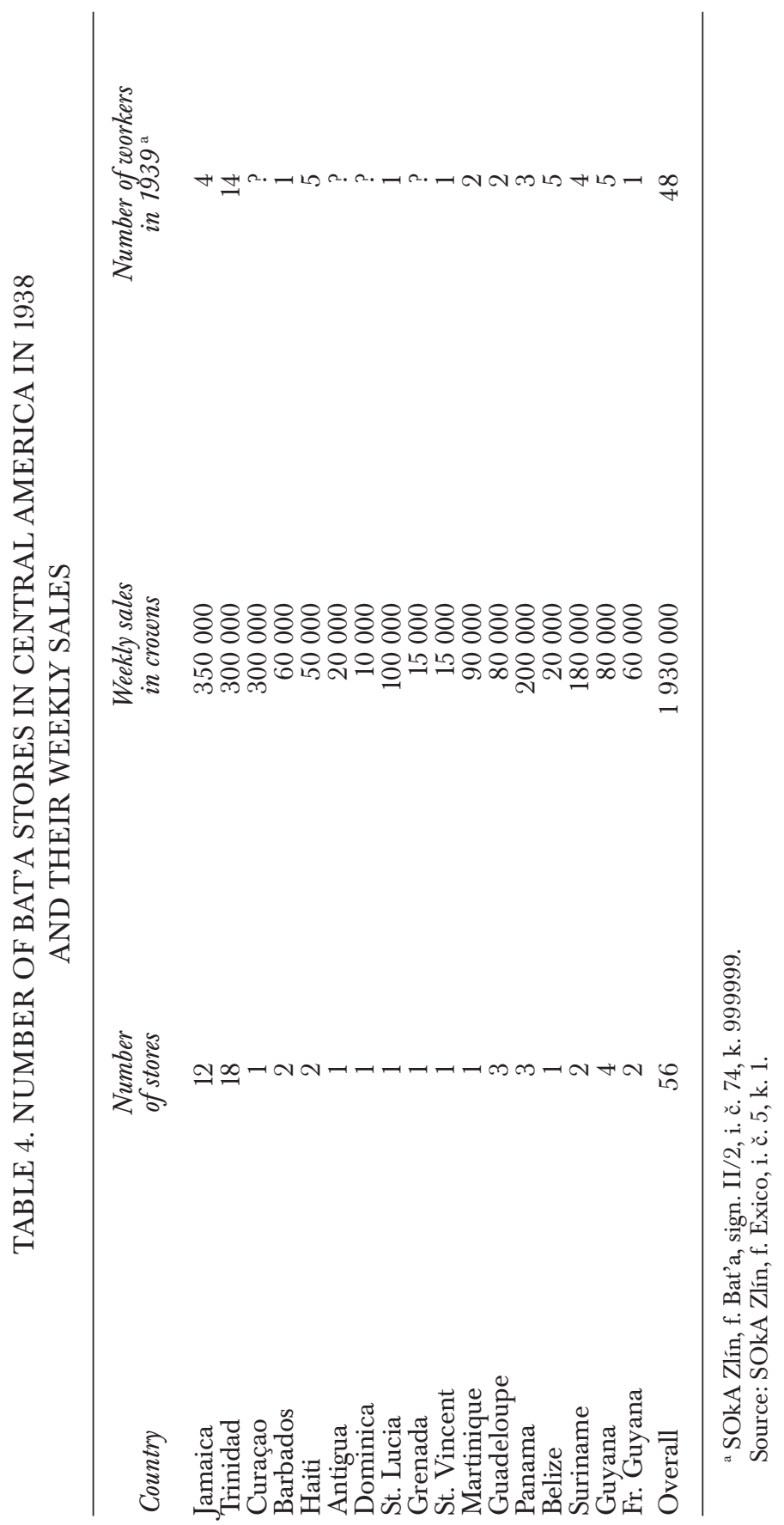


and Suriname. Expansion and holding positions on the markets of Mexico, Nicaragua, Puerto Rico or Cuba was not a success. Similarly, the company could not establish a sister company nor a factory directly in each of the region's countries. This was only done in Guatemala in 1940, under conditions changed by war, when the Zlin headquarters were controlled by the German occupation powers and its contacts with Central America and the Caribbean ceased.

\section{BAT’A IN PANAMA}

Panama has always been a somewhat exceptional country compared to its neighbours. It is not considered a part of Central America, as its independence was gained in 1903 and not from Spain but from Colombia. Another difference is the famous Panama Canal and an economic model dissimilar from the ones in its neighbouring states, which also influenced Bat'a's penetration of the local market. First, in the interwar period there was a special Canal Zone, which tied Panama closer to the United States. As a result, the US dollar was used as currency here. Also, Panama did not have the central bank, which prevented the government from issuing strong protectionist policies. This was the reason, among other, why Panama had one of the lowest customs tariffs in the area. Another advantage was the strategic position of the country, labelled by many as "the crossroads of the world", between North and South America, Europe, Africa and Australia, Asia. This meant a lot of marine traffic that brought, among others, soldiers, seaman, and tourists to the area, in other words, potential customers. To conclude, although Panama (without the Canal Zone) had just about half a million citizens at that time, it was the biggest importer of merchandise. The reason for this was that a large portion of the products brought here was used for re-export, usually to its neighbours (NAČR, $f$. Exportní ústav, k. 290, Korespondence s agencií v Panamě, Glücksmann to Czech Export Institute, doc. 6, 19. 5. 1936) (see figure 2).

Bat'a quickly realised the opportunities in the country of the isthmus. It is no surprise that his exports were the biggest here out of Spanishspeaking states and the clear advantages could not be overlooked. Also, it is important to point out that Bat'a had one factory in the US in New York, which facilitated his situation here. The first representative sent to Panama was Cyril Eduard Glücsksmann, who operated in Panama from 1935 but maybe even earlier. He came from the town of Luhačovice near Zlín, so he was likely to have had previous contacts with the company. In Panama, he represented not only Bat'a but several other Czechoslovak companies, and when the Czechoslovak Export Institute was looking for someone to 
start its agency in Panama in 1935, he was appointed as he was already well established in the isthmus country (NACR, f. Exportní ústav, k. 140, Korespondence s vyslanectvím Caracas).

It is believed that Bat'a's presence in Panama started with Glücksmann because prior to 1933 the company sent in the total of 3400 pairs of shoes. In 1934 the export rose to 13000 pairs. Nevertheless, we cannot be sure if it was influenced by Glücksmann or not, as there is no evidence. The following year, a further growth to 72000 pairs was recorded, i.e. almost sixfold. This time Glücksmann's role is unquestionable (SOkA Zlín, f. Bat'a, sign. XXVI, i. č. 105, k. 1852). In 1936, he parted with Bat'a criticizing hisorganizational methods and employee policy (NACR, f. Exportní ústav, k. 290, Korespondence s agencií v Panamě, Glücksmann to Czech Export Institute, document without number, 11.4.1936). The company was better off without him, although the same year due to the reorganization and the opening of a new shop the company suffered a loss as the exports dropped to 58000 pairs (part of the existing number still owing to Glücksmann) (SOkA Zlín, f. Bat'a, sign. XXVI, i. č. 105, k. 1852). It is true that Bat'a's first director in Panama was agile and had many local contacts; on the other hand, since 1936 he was overwhelmed with work and started to promote other Czechoslovak products. He organized a small exposition the same year and started his own Czechoslovak Import Company. In 1937, he wanted to build a consignment warehouse and in 1938, he arranged a crystal cup from a school in Český Brod for the Central American and Caribbean Games (NACR, f. Exportní ústav, k. 141, Korespondence s vyslanectvím Caracas). The problem was that he borrowed a lot of money to pursue his objectives and sadly went bankrupt at the beginning of 1938. In the agency of Czechoslovak Export Institute, his assistant Jan Filip substituted him, but soon the institute ceased to exist.

However, this was not the end of Bat'a's presence in Panama. After the year of reorganization and building of two shops -one in Panama City and the other in Colon- the concern sent an outstanding organiser, Alfred Fischgrund, to Panama, who had spent a year, since the spring of 1937 in Central America before he relocated to the Philippines. During his stay, Bat'a sold 99000 pairs of shoes in 1937 and 151000 the following year. This happened not only because of his skills but also due to the favourable circumstances. Firstly, it was the lowering of tariffs for high quality merchandise not produced in Panama as the government wanted to protect the tourists from buying cheap imitations (NACR, f. Exportní ústav, k. 290, Korespondence s agencií v Panamě, Glücksmann to Czech Export Institute, doc. 26, 2. 3. 1937). Among the reasons, there were also the Central American and Caribbean Games in February 1938 and the famous carnival at the same time visited by tourists from the United States, 


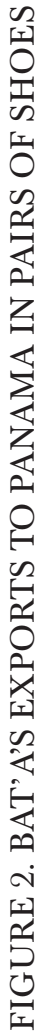

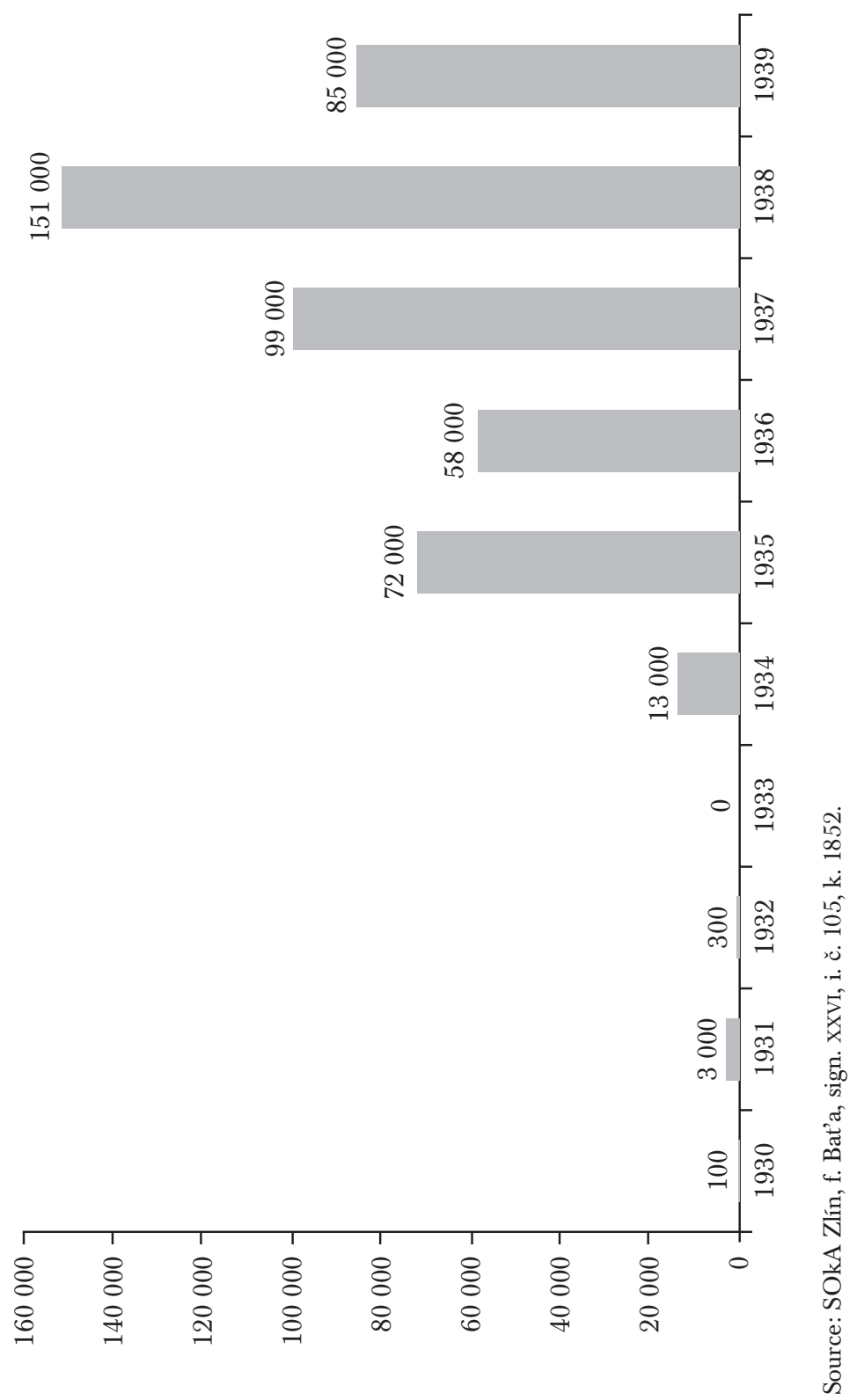


Central America, the Caribbean, Venezuela and Colombia which left the shop empty (sold out) (Zlin, 31. 8. 1938, p. 7).

Fischgrund quickly realised that Panama was indeed the "crossroad of the world" and understood that focusing on the passengers could be more beneficial for his business there. "Apart from selling to the locals, all my effort was to attract the attention of tourists which proved right" (Zlin, 24. 8. 1938 , p. 3). Another rarity of Panama, which he understood, was its importance for re-exporting, meaning that people who bought Bat'a's shoes in Panama later used them to exchange goods. He wrote about one particular example of a merchant living on his boat with all his possessions. "Señor Moreno would sail around the islands but he did not want to tell me which ones as he was scared of competition. And on those islands he would buy coconuts, bananas and coffee from the locals, and he would pay for this merchandises with our shoes, necklaces from Jablonec or tools, depending what the customers liked" (Zlin, 24. 8. 1938, p. 3).

He also made a small list of his customers and their preferences, which was very useful. He mentions that the locals, the "Indians" who were trying to exchange the shoes for coconuts, wanted mainly cheap textile shoes with rubber soles. The gold prospectors working in the hard terrain preferred rubber boots. The rich tourists especially from the United States and also the soldiers stationed in the Canal Zone demanded solid and expensive all-leather shoes. It is hardly surprising that in 1938 Bat'a sold 36608 pairs of this type there, which is a number that could only be rivalled by Trinidad and Tobago, and Curaçao (SOkA Zlín, f. Bat'a, sign. XXVI, i. č. 105 , k. 1852). Fischgrund also mentions that Chinese immigrants preferred slippers and the United States sailors asked for white textile shoes (Zlin, 24. 8. 1938, p. 3).

The year 1938 saw another change for Bat'a in Panama. Fischgrund was transferred to the Philippines and his place was taken by Antonín Liška, who spent at least two years there (SOkA Zlín, f. Exico, i. č. 152, k. 11). He inherited an excellent market position that was improved by a large demand for tyres in Panama in 1938 (NACR, f. Exportní ústav, k. 290, Korespondence s agencií v Panamě, Filip to Czech Export Institute, doc. 2, 18. 1. 1939). That year Bat'a sent in merchandise with a value of 140681 Czechoslovak crowns to this Central American country, i.e., more than into any other state in the area. The following year Bat'a's exports declined; however, it was due to the global circumstances. The Second World War started and the connection between America and Central Europe ceased. Therefore in 1939, the company sold only 85000 pairs of shoes in Panama, half of the amount from the year before (SOkA Zlín, f. Bat'a, sign. XXVI, i. č. 105, k. 1852). 


\section{ExPANSION to PUERTo Rico}

The beginnings of the company's penetration into the territory of Puerto Rico are related to February 1934, when a Bat'a salesman Otto Maršálek arrived from Zlín. The company commissioned him to explore the local market and build wholesale sales. Maršálek recognized the complexity of the situation soon after his arrival. From conversations with local traders, he learned that the wholesale prices for which he wanted to supply the goods were too high and comparable to the prices of the retail store. The width of Bat'a's shoes also did not fit the local population. Standard European footwear could only be sold in the island's interior, and the residents in coastal cities found narrow footwear imported from the United States of America more suitable. In San Juan, the largest city on the island, there was a fierce competition of fourteen other shoe dealers, who offered cheap US-made footwear. These shoes, referred as "job lots" consisted of samples, clearance sales and surpluses, and they were of good quality despite the low price. In addition, Maršálek did not find suitable commercial premises in San Juan to set up a shop, because every well-placed sales location was already leased or a very high rent was asked for it. On his arrival, Maršálek received a supply of shoes that did not suit the local conditions. He recalls:

The stock, which was expedited at the time of my departure from Zlín, consisted mostly of different sort of European wider shoes. I tried to sell them in rural towns. However, there was a problem with the price, because in inland towns sales prices were even lower than in the coastal cities due to worse economic conditions. Regular types of footwear cannot be sold in towns, as the customers buy only "job lots"; ordinary people have little or no money, and wealthy citizens make their purchases in San Juan, as travelling within the island is very cheap (SOkA Zlín, $\mathrm{f}$. Bat'a, sign. II/2, i. č. 12 , k. 1066 , p. č. 40).

For the above reasons, he did not recommend the company headquarters in Zlín to open their own shops nor to introduce wholesale sales. To review Maršálek conclusions, a Rayonist Julius Valenta came from Jamaica, and decided to introduce retail trading. The first store was opened on May 4, 1934 in San Juan, and a few weeks later the second shop (led by Mr. Marčan) opened in the town of Ponce, on the southern shore of the island. To improve footwear sales, promotional material was missing. So Bat'a's merchants had to produce hand-made billboards, price tags and advertising posters, all within their limited financial means. The local market was not suitable for the European footwear collection, as no one on the island 
was buying the shoes of a large size and width. Customers also did not show much interest in canvas shoes. Maršálek asked the Zlín headquarters for a supply of an American shoe collection, which would have better sales prospects. He remembers the difficulties:

My reports were not received well in Zlín. On the contrary, it was said that the European collections are very well accepted by the surrounding islands, and that such differences in Puerto Rico are not possible. They sent more merchandise from Europe, and the stock, which sold only slowly in the meantime, increased in a few weeks by the stock from Bermuda (SOkA Zlín, f. Bat'a, sign. II/2, i. č. 12, k. 1066, p. č. 40).

Such unfavourable circumstances led to poor shoe sales. In the first half of 1934, only 611 pairs of shoes were sold for US\$ 1026 . In October 1934, the Bat'a's Manager for the Central American region Arpad Ronai arrived on an inspection trip to Puerto Rico only to find out that Maršálek's reports were true, and the situation of the stores and the sale of footwear was indeed poor. During his presence on the island, finally a new shipment of footwear arrived from the American collection, which significantly increased sales. On Ronai's advice, the shop staff worked out a new supply statement taking into account the needs of local residents, so that the stores were properly stocked for women, children and rubber footwear for Christmas. However, transport problems caused children and women goods to arrive to the stores only after Christmas, so the sales season was weak. In the second half of 1934, 6858 pairs were sold for a total of US\$ 9 870, after deducting the operating costs and wages, the stores on Puerto Rico made the profit of US\$ 466. In January and February 1935, an attempt was made to increase the turnaround of Puerto Rico stores by supplying wholesale on the neighbouring St. Thomas. Sales on this island were successful, as turnover in March and April exceeded sales from the Christmas season. Despite this success, the company's store was not set up on the island and the sale of the products went through wholesalers. In the following years, the wholesale on St. Thomas was successful, as evidenced by the increasing exports of footwear from Zlín -10 000 pairs in 1935, 23000 pairs in 1938 (SOkA Zlín, f. Bat'a, sign. X, i. č. 118, k. 1541).

In the spring of 1935, the main Puerto Rican store in San Juan expanded when the neighbouring sales premises were leased. The shop had more windows, and the monthly rent rose from US\$ 90 to US\$225. Nevertheless, the new goods did not arrive and only the non-sellable last year's collection remained in the warehouses. Because of this Maršálek had to go back to Zlín in July to supervise the preparations for the new collection. He returned to Puerto Rico in the middle of August 1935, but continued 
to struggle -the new goods arrived late in mid-October when they were no longer up to date, the ordered advertising posters did not arrive at all and Bat'a representatives in Puerto Rico did not have sufficient funds to make their own advertising banners. His estimation of the sales of rubber footwear during the winter months also were not confirmed, as customers were no longer interested in this type of footwear -it was not a novelty as before, and the shoes were not practical because of the heat. An attempt to introduce wholesale sales in the more remote parts of the island did not work either and, in addition, Japanese competitors imported shoes at a lower price. All these factors brought about unfavourable results for stores; in the first half of 1935, only 13990 pairs of shoes were sold for US\$ 14 266. In the second part of the year, sales figures were even worse as just 12506 pairs worth US\$ 12266 were sold. After deducting operating costs, the annual profit of Puerto Rican stores was US\$ 3 324. Aware of his failure, Maršálek asked his superiors to remove him from Puerto Rico in February 1936. The company, which also started to withdraw from Puerto Rico, accepted his request (SOkA Zlín, f. Bat'a, sign. II/2, i. č. 12, k. 1066, p. č. 40) (see figure 3).

Bat'a's business in Puerto Rico failed. After Maršálek's departure, both shops were gradually closed, and from 1938, the company was no longer present on the island. The import of footwear decreased -15000 pairs (in 1934), 27000 pairs (in 1935), 16000 pairs (in 1936), 2000 pairs (in 1937), 1000 pairs (in 1938) and in 1939 Bat'a did not export to Puerto Rico at all (SOkA Zlín, f. Bat'a, sign. x, i. č. 118, k. 1541) (see map 2).

\section{CONCLUSions}

This paper proves that in the 1930s the famous Czech shoe company Bat'a attempted to expand to other markets outside Europe. As the Great Depression diminished the exports to its traditional partners, Bat'a had to diversify the portfolio of markets. This firm was not the only one who tried these measures, other Czechoslovak or European companies like Škoda or Zbrojovka soon followed and even the governments took interest in facilitating the trade between relatively peripheral economies. The decade of 1930 was important in the establishment of Export Institutes across $\mathrm{Eu}-$ rope and their agencies around the world.

Places as Mexico, Central America, and the Caribbean were among the regions Bat'a was interested. However, due to unfavourable circumstances its supplies there were uneven depending on the respective country's tariff policy or its status as a colony. The major economic crisis and the subsequent increase of customs barriers and import restrictions forced 


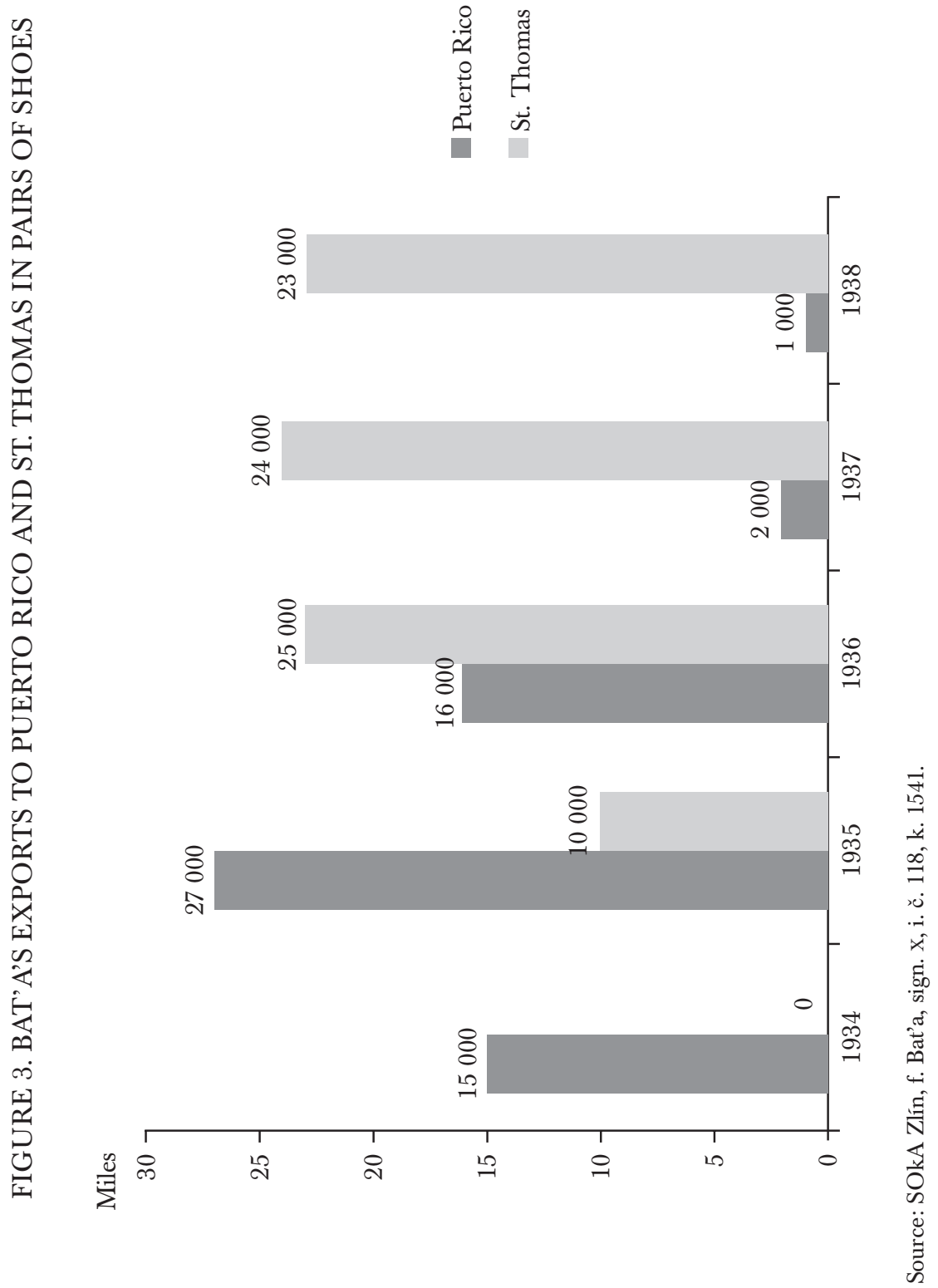




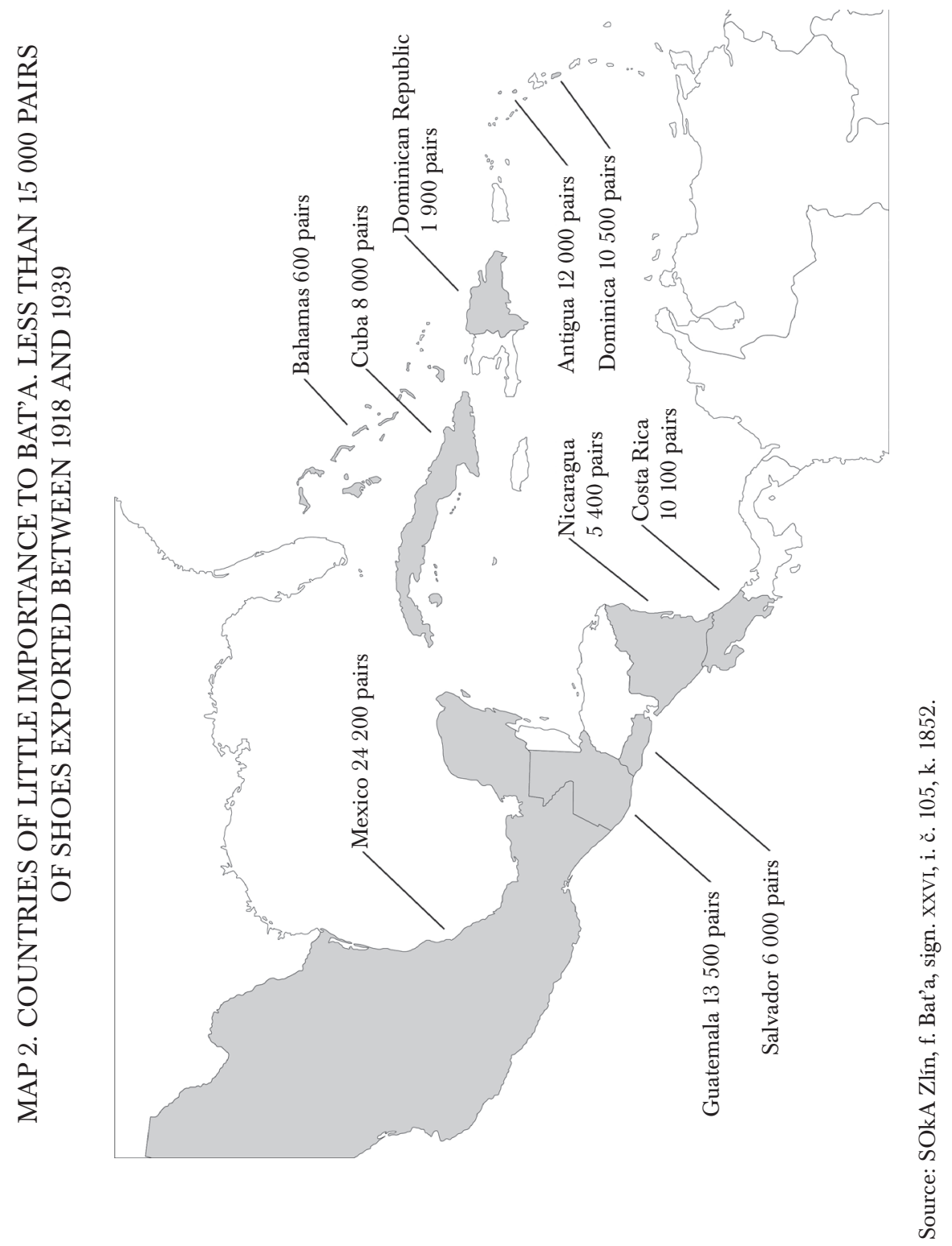


Bat'a to establish sister companies and manufacturing units abroad. Bat'a also opened its own stores in other countries in order to improve the sales. To keep the price of the shoes low, a low-cost delivery of the goods was required. This was provided by the Bat'a factories abroad, which would supply shops in the country's colonies under only minor import restrictions. Owing to the lowest duties in the Dutch colonies, the largest market for Bat'a footwear were regions under the influence of the Netherlands. These were followed by the British colonies and dominions. In those territories, the Bat'a Company business was most developed and prosperous, while the independent states, such as Cuba, Guatemala, and Mexico, did not allow the company to expand into their markets, and its products were poorly represented there. Nevertheless, the case of Panama was rather specific, a sovereign state, which did not prevent the import of Bat'a shoes. This was because of the extraordinary location of the state -a crossroad of the world- and the US-controlled Canal Zone. Panama was, therefore, an ideal place for the re-export of Bat'a's goods.

There were other reasons why Bat'a was interested in certain countries. The Czechoslovak government and its activity, for instance, played an important role. Especially at the end of the 1930's, states like Mexico, Panama or Guatemala imported more shoes than in the previous years. This could be explained by the presence of the Czech Export Agency in those countries or the trade agreements signed between the governments (especially in the case of Guatemala). Even though in some states of the area we researched, Bat'a's presence was rather negligible, we wish to emphasise that Bat'a was the only Czechoslovak company that entered these markets. Even the famous Česká Zbrojovka or Škoda exported primarily to Southern America. In addition, it is very important to realise that the company's presence in the territory in the 1930s led to an even bigger expansion during the Second World War, when factories were established in Haiti or Guatemala in 1940. This growth was soon followed by sister companies and budding business activities in the respective countries. Similarly, after the war, when the Czechoslovak government confiscated and nationalised Bat'a factories, stripping the company Bat'a of its assets in Central and Eastern Europe, the succeeding Bata Shoe Company, from its base in Canada, extensively used the infrastructure and contacts the Bat'a corporation had made before and during the conflict. 


\section{REFERENCES}

Baros, J. (1945). The first decade of batangar. Batangar: The Club for the Graduates of Bata School.

Bethell, L. (ed.) (2008). The Cambridge history of Latin America, volume VI, part 1. Cambridge: Cambridge University Press.

Bulmer-Thomas, V. (2003). The economic history of Latin America since independence. Cambridge: Cambridge University Press.

Coatsworth, J. H. \& Williamson, J. G. (2002). The roots of Latin American protectionism: Looking before the Great Depression. National Bureau of Economic Research Working Paper 8999. Cambridge, National Bureau of Economic Research. DOI: 10.3386/w8999

EHrenbold, T. (2012). Bata. Schuhe für die Welt, Geschichten aus der Schweiz. Baden: Verlag für Kultur und Geschichte.

Eichengreen, B. \& Irwin, D. A. (2010). The slide to protectionism in the Great Depression: Who succumbed and why? The Journal of Economic History, 70(4), 871-897. DOI: $10.1017 / \mathrm{S} 0022050710000756$

Gatti, A. (2004). Chausser les hommes qui vont pieds nus. Metz: Serpenoise.

HodÁč, X. F. (2015). Tomáš Bat'a, Život a práce hospodářského buditele. Zlín: Univerzita Tomáše Bati ve Zlíně.

Hrelja, K. \& Kaminski, M. (1971). “Borovo” Jugoslavenski Kombinat Gume i Obuće. Slavonski Brod: Historijski Institut Slavonije.

Kálmán, H. (1974). Tisza Cipögyár. Martfü: Szolnok Martfü.

Kindelberger, C. G. (1985). La crisis económica 1929-1939. Barcelona: Crítica.

Knight, A. \& Drinot, P. (eds.) (2015). La Gran Depresión en América Latina. Mexico City: Fondo de Cultura Económica.

LeHár, B. (1960). Dějiny Bat’ova koncernu (1894-1945). Prague: Státní Nakladatelství Politické Literatury.

MareK, M. (2017). Středoevropské aktivity Bat'ova koncernu za druhé světové války. Brno: Matice Moravská.

Pagáč, J. (1926). Tomáš Bat’a a 30 let jeho podnikatelské práce. Prague: Sfinx.

Pokluda, Z. (2015). Ze Zlína do světa - príběh Tomáše Bati =From Zlin into the world - the story of Tomas Bata. Zlín: Nadace Tomáše Bati.

Rоотн, T. (1993). British protectionism and the international economy: Overseas commercial policy in the 1930s. Cambridge: Cambridge University Press.

ŠEvečEK, O. \& Jemelka, M. (eds.) (2013). Company towns of the Bat'a concern. Stuttgart: Franz Steiner Verlag.

ŠEvečEK, O. \& Jemelka, M. (2016). Tovární města Batova koncernu. Evropská kapitola globálni expanze. Prague: Academia.

VaňHara, J. (1994). Přiběh jednoho muže a jednoho města. Zlín: J. Vaňhara.

Widmer, M. (1990). Die Bata Kolonie in Möhlin(Master Thesis). ETHZürich, Switzerland. 
Archives

AHGE Archivo Histórico Genaro Estrada, Mexico City, Mexico.

AMZ Archiv Ministerstva Zahraničních Věcí České Republiky (Archive of Foreign Relations Ministry of Czech Republic), Prague, Czech Republic.

NAČR Národní Archiv České Republiky (National Archive of Czech Republic), Prague, Czech Republic.

SOkA Státní Okresní Archiv Zlín (State District Archive Zlín), Zlín, Czech Republic. 